\title{
KADAR C ORGANIK SETELAH PERIODE TANAM PADI KE DUA DENGAN APLIKASI BIOCHAR PADA LAHAN BEKAS TAMBANG BATU BATA DI POTORONO YOGYAKARTA
}

\section{(THE ORGANIC CARBON CONTENT AFTER SECOND RICE PLANTING PERIOD WITH BIOCHAR APPLICATION ON PASCA BRICK MINING LAND IN POTORONO YOGYAKARTA)}

\author{
Kamaratih Nisrina Pertiwi $^{1)}$, Susila Herlambang ${ }^{2 *)}$ dan M Nurcholis $^{2)}$ \\ ${ }^{1)}$ Prodi Agroteknologi, Universitas Pembangunan Nasional Veteran Yogyakarta \\ ${ }^{2)}$ Prodi Ilmu Tanah, Universitas Pembangunan Nasional Veteran Yogyakarta \\ ${ }^{*}$ Corresponding author E-mail: susilaherlambang@upnyk.ac.id
}

\begin{abstract}
The Anthraquic Typic Epiaquepts was paddy soil after brick mining at Potorono, Banguntapan, Bantul, Yogyakarta. It has low nutrients and organic $\mathrm{C}$ level. The effect of residue soil ameliorant ie: biochar, cow dung and bagasse, hopefully, can increase the $\mathrm{C}$ organic and nutrients after both first and second planting. The purpose of this study was to determine the effect of the residual ameliorant and incubation in two seasons of paddy plantation of organic $\mathrm{C}$ levels, total $\mathrm{N}, \mathrm{P}$ available, $\mathrm{pH}\left(\mathrm{H}_{2} \mathrm{O}\right)$ and Cation Exchange Capacity (CEC). This study used a split plot on Randomized Block Design (RCBD) method. The dosage used was 15 tons/ha of coconut shell biochar residue, sugarcane bagasse, and cow dung and there were 36 experiment plots. The parameters observed were organic $\mathrm{C}, \mathrm{N}$-Total, P-Available, $\mathrm{pH}\left(\mathrm{H}_{2} \mathrm{O}\right)$, Cation Exchange Capacity (CEC). The results shows that the soil with residual Biochar coconut shell has no significant difference in $\mathrm{C}$ organic, total $\mathrm{N}, \mathrm{pH}\left(\mathrm{H}_{2} \mathrm{O}\right)$, and Cation Exchange Capacity (CEC), but it is significantly different in P-available soil. The residual biochar has the highest organic $\mathrm{C}$ level of $1.76 \%$. The residual Biochar coconut shell can increase the Cation Exchange Capacity (CEC) from $5.83 \mathrm{Cmol}(+) \mathrm{kg}-1$ to $7.85 \mathrm{Cmol}(+) \mathrm{kg}-1$. The P- available soil with residual Biochar coconut shell is the highest, which is $20.32 \mathrm{ppm}$.
\end{abstract}

\section{Keyword : Anthraquic Typic Epiaquepts, Biochar, Corganic, Coal mining}

\begin{abstract}
ABSTRAK
Anthraquic Typic Epiaquepts pada tanah sawah yang digunakan penelitian merupakan lahan setelah penambangan batu bata di Potorono, Banguntapan, Bantul, Yogyakarta. Tanah bekas penambangan batu bata memiliki nutrisi dan tingkat $\mathrm{C}$ organik rendah. Pemberian limbah organikyang merupakan bahan pembenah tanah yaitu: biochar, kotoran sapi dan ampas tebu diharapkan dapat meningkatkan $\mathrm{C}$ organik dan unsur hara baik setelah tanam pertama maupun kedua. Tujuan penelitian adalah untuk mengetahui pengaruh limbah organik sebagai amelioran dan waktu inkubasi dilakukan pada dua kali tanam padi. Analisa laboratorium yang dikaji adalah kadar $\mathrm{C}$ organik, $\mathrm{N}$ total, $\mathrm{P}$ tersedia, $\mathrm{pH}\left(\mathrm{H}_{2} \mathrm{O}\right)$ dan Kapasitas perukaran kation (KPK). Penelitian ini menggunakan plot terpisah dengan metode Rancangan Acak Kelompok (RAK). Dosis yang digunakan adalah residu biochar tempurung kelapa, ampas tebu, dan kotoran sapi sebanyak 15 ton / ha dengan jumlah 36 petak percobaan. Parameter yang diamati adalah $\mathrm{C}$ organik, N-Total, P-Tersedia, pH $\left(\mathrm{H}_{2} \mathrm{O}\right)$, Kapasitas perukaran kation (KPK). Hasil penelitian
\end{abstract}


menunjukkan bahwa tanah dengan limbah organik biochar tempurung kelapa tidak memiliki perbedaan yang nyata pada $\mathrm{C}$ organik, $\mathrm{N}$ total, $\mathrm{pH}\left(\mathrm{H}_{2} \mathrm{O}\right)$, dan Kapasitas perukaran kation (KPK, tetapi berbeda nyata pada tanah $\mathrm{P}$ tersedia. Biochar residual memiliki kadar $\mathrm{C}$ organik tertinggi sebesar $1,76 \%$. Sisa batok kelapa Biochar dapat meningkatkan Kapasitas perukaran kation

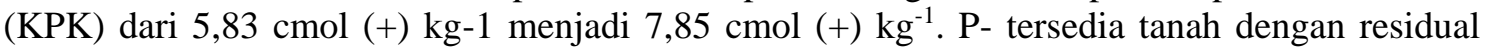
biochar tempurung kelapa paling tinggi, yaitu 20,32 ppm

Kata kunci : Anthraquic Typic Epiaquepts, Biochar, Corganik, Tambang Batu Bara

\section{PENDAHULUAN}

Tanah sawah di Desa Potorono, Banguntapan, Bantul, Yogyakarta termasuk dalam golongan jenis tanah Inceptisol sub group Anthraquic Typic Epiaquepts, berasal dari endapan alluvial Gunung Merapi. Pada jenis tanah sawah Anthraquic Typic Epiaquepts di Desa Potorono, Banguntapan, Bantul, Yogyakarta merupakan tanah bekas industri batu bata, masyarakat telah mengambil top soil untuk pembuatan batu bata. Oleh karena itu, untuk memperbaiki kesuburan tanah diperlukan bahan masukan tinggi berupa amelioran dan bahan organik yang berfungsi dapat memperbaiki ketersediaan unsur hara dan C organik didalam tanah Anthraquic Typic Epiaquepts (Afifi, 2019) tersebut, seperti: biochar dan Pupuk Kandang Sapi.

Biochar adalah arang hayati hasil dari proses pembakaran biomassa pada keadaan oksigen terbatas atau tanpa oksigen (Glaser et al. 2001). Penambahan Biochar sebagai ameliorant tanah diharapkan dapat menyimpan karbon lebih lama dalam tanah sehingga dapat memberikan dampak positif pada residu perlakuannya setelah dua musim tanam. Penelitian ini dilakukan sebagai penelitian lanjutan dari peneliti sebelumnya Setyaji (2018), dimana mengetahui pengaruh Biochar tempurung kelapa, ampas tebu dan kotoran sapi setelah pengaplikasian. Oleh karena itu, dilakukan penelitian lanjutan untuk mengetahui apakah residu Biochar tempurung kelapa, ampas tebu dan kotoran sapi masih dapat mempertahankan nilai $\mathrm{C}$ organik, $\mathrm{N}$ total, $\mathrm{P}$ tersedia, $\mathrm{KPK}$ dan $\mathrm{pH}$ $\left(\mathrm{H}_{2} \mathrm{O}\right)$. Biochar tempurung kelapa mengandung karbon $\geq 42,01 \%$ sehingga dapat digunakan untuk bahan organik tanah. Kotoran sapi dipilih karena banyak mengandung hara yang dibutuhkan tanaman seperti nitrogen, fosfor, kalium, kalsium, magnesium, belerang dan boron (Sudarkoco, 1992). Sedangkan ampas tebu sebagian besar mengandung lignin, sellulose dan mengandung kadar C 13,324\%, kadar N 0,422\%, C/N 31,57, dan pH 7 (Guntoro, 2003). Kadar C organik pada biochar tempurung kelapa juga dipengaruhi oleh beberapa faktor lingkungan seperti $\mathrm{pH}\left(\mathrm{H}_{2} \mathrm{O}\right)$ tanah, iklim dan lain lain. Kotoran sapi menunjukan hasil $\mathrm{C}$ organik yang tinggi pada penelitian sebelumnya sedangkan pada ampas tebu menunjukan hasil KPK yang tinggi karena fraksi humus yang tinggi. Atas dasar tersebut diatas dilakukan penelitian residu pemberian biochar tempurung kelapa, ampas tebu dan kotoran sapi pada dua musim pertanaman tanaman padi di tanah Anthraquic Typic Epiaquepts di Desa Potorono, Banguntapan, Bantul, Yogyakarta untuk mengetahui peningkatan kadar $\mathrm{C}$ organik tanah, $\mathrm{N}$ total, $\mathrm{P}$ tersedia, $\mathrm{pH}\left(\mathrm{H}_{2} \mathrm{O}\right)$ dan KPK. 


\section{BAHAN DAN METODE}

Penelitian ini merupakan penelitian pada musim tanam kedua sebagai penelitian lanjutan. Penelitian menggunakan Rancangan Acak Kelompok (RAK) dengan pola Split Plot. Tanaman indikator mengunakan padi varietas Inpari Sidenuk. Adapun perlakuan pada musim tanam pertama dan kedua terdiri dari 4 residu perlakuan yaitu Faktor I: Kontrol (0 ton/ha), Kotoran Sapi (15 ton/ha), Biochar (Tempurung Kelapa) (15 ton/ha), Ampas tebu (15 ton/ha) dan Faktor II: Inkubasi 1 bulan sebelum tanam pertama tanaman Padi, Inkubasi 2 bulan sebelum tanam pertama tanaman Padi, Inkubasi 3 bulan sebelum tanam pertama tanaman Padi. Penelitian ini dimulai dengan analisis tanah setelah tanam pertama yang diambil pada 36 petak ukuran 4 x 4 m yang sama dengan penelitian terdahulu pada tanah dengan residu perlakuan biochar tempurung kelapa, ampas tebu dan kotoran sapi dengan dosis 15 ton/ha dengan inkubasi 1 bulan, 2 bulan dan 3 bulan. Parameter yang dianalisis yaitu $\mathrm{C}$ organik, $\mathrm{N}$-total, $\mathrm{P}$-tersedia, $\mathrm{pH}\left(\mathrm{H}_{2} \mathrm{O}\right)$ dan Kapasitas Pertukaran Kation.Penanaman padi musim pertanaman kedua dilakukan setelah tanah dibajak, dengan jarak tanam $15 \times 15 \mathrm{~cm}$. Jenis padi yang digunakan adalah padi Sidenuk. Setelah penanaman padi, dilakukan perawatan padi yaitu dengan pengairan untuk memenuhi kebutuhan air dengan irigasi, pengendalian hama dan pemupukan dengan Urea 50kg dan Phonska 50kg. Setelah panen dilakukan pengambilan sampel yang kedua pada petak percobaan secara diagonal untuk analisis parameter $\mathrm{C}$ organik, N-total, P-tersedia, $\mathrm{pH}\left(\mathrm{H}_{2} \mathrm{O}\right)$ dan Kapasitas Pertukaran Kation.

\section{HASIL DAN PEMBAHASAN}

Tanah di desa Potorono merupakan lahan subur dengan dibudidayakan tanaman padi sawah, namun setelah dilakukan kegiatan penambangan tanah untuk keperluan pembuatan industri batu bata mengalami kemerosotan tanah (Tabel 1). Kehilangan tanah bagian atas menyebabkan kualitas tanah menurunkan produksi padi sawah. Hal ini dikarenakan adanya perubahan sifat fisik, kimia dan biologi tanah.

Tabel 1. Beberapa Sifat Kimia pada Tanah Anthraquic Typic Epiaquepts di Potorono, Banguntapan, Yogyakarta

\begin{tabular}{ccc}
\hline Parameter & Hasil & Harkat (PPT, 1986) \\
\hline $\mathrm{pH}\left(\mathrm{H}_{2} \mathrm{O}\right)$ & 6,88 & Netral \\
$\mathrm{C}$ organik (\%) & 0,40 & Rendah \\
KPK cmol(+) $\mathrm{kg}^{-1}$ & 6,28 & Rendah \\
N-total (\%) & 0,08 & Rendah \\
P-tesedia (ppm) & 9,5 & Sangat Tinggi \\
tersedia (ppm) & 54 & Tinggi \\
Tekstur Tanah: & & Geluh Pasiran \\
Pasir (\%) & 59 & \\
Debu (\%) & 30 & \\
Lempung (\%) & 11 & \\
\hline
\end{tabular}

Sumber: Herlambang et al., 2018. 
$\mathrm{pH}\left(\mathrm{H}_{2} \mathrm{O}\right)$ tanah menunjukan hasil sebesar 6,88 dan termasuk dalam harkat yang netral. $\mathrm{C}$ organik tanah mempunyai nilai sebesar $0,4 \%$ yang termasuk dalam harkat rendah. $\mathrm{N}$ total sebesar $0,08 \%$ dan KPK sebesar $6,28 \mathrm{cmol}(+) \mathrm{kg}^{-1}$ termasuk dalam harkat rendah. Kandungan bahan organik dalam tanah Anthraquic Typic Epiaquepts Potorono masih kurang, kurangnya kandungan bahan organik ini dapat diakibatkan karena tanah Anthraquic Typic Epiaquepts karena telah diambil pada top soilnya, untuk pembuatan batu bata sehingga meninggalkan subsoil yang relatif kurang subur. Karena memiliki kandungan bahan organik rendah maka kapasitas tukar kation tanah tanah juga rendah, sehingga relatif kurang kuat memegang hara dan karenanya unsur hara mudah tercuci. $\mathrm{N}$ total tanah rendah karena $\mathrm{N}$ mengalami denitrifikasi, $\mathrm{N}$ berubah menjadi $\mathrm{N}$ udara dan $\mathrm{NO}_{2}$ sehingga $\mathrm{N}$ menjadi tidak tersedia. $\mathrm{P}$ tersedia menunjukan harkat yang sangat tinggi, karena $\mathrm{pH}\left(\mathrm{H}_{2} \mathrm{O}\right)$ tanah netral maka ketersediaan $\mathrm{P}$ pada tanah menjadi maksimum. $\mathrm{K}$ tersedia diperoleh hasil sebesar 54 yang tergolong tinggi. Kalium dalam tanah Anthraquic Typic Epiaquepts ditemukan dalam mineral-mineral yang telah terlapuk sehingga ion-ion kalium yang dilepaskan dapat diabsorbsi pada kation tertukar dan cepat tersedia kembali untuk diserap.

\section{C organik Tanah Setelah Tanam Pertama Tanaman Padi}

Karbon organik tanah setelah tanam pertama tanah Anthraquic Typic Epiaquepts, Potorono, Banguntapan, Bantul, Yogyakarta menunjukan bahwa kontrol ada beda nyata dengan residu perlakuan biochar, residu perlakuan ampas tebu dan residu perlakuan kotoran sapi (Tabel 1), tetapi pada residu perlakuan biochar, ampas tebu dan kotoran sapi menunjukan tidak beda nyata.Tanah residu biochar dapat meningkatkan nilai $\mathrm{C}$ organik paling tinggi, inkubasi 2 bulan mengalami peningkatan karena mengalami penambahan bahan organik dari sisa akar tanaman padi pada saat panen. Inkubasi 3 bulan mengalami peningkatan dibanding inkubasi 2 bulan karena inkubasi 3 bulan lebih lama terdekomposisi sehingga bahan organiknya lebih tinggi maka karbon lebih tinggi.

Tabel 2. C organik (\%) tanah setelah tanam pertama tanaman padi pada Anthraquic Typic Epiaquepts Potorono, Yogyakarta

\begin{tabular}{lcccc}
\hline \multirow{2}{*}{ Perlakuan } & \multicolumn{2}{c}{ Inkubasi Sebelum Tanam Pertama } & \multirow{2}{*}{ Rerata } \\
\cline { 2 - 4 } & 1 bulan & 2 bulan & 3 bulan & \\
\hline Kontrol & 1.2914 & 1.3111 & 1.3323 & $1.3142 \mathrm{q}$ \\
Biochar Tempurung Kelapa & 1.5933 & 1.7112 & 1.9625 & $1.7625 \mathrm{p}$ \\
Ampas Tebu & 1.5443 & 1.7512 & 1.5227 & $1.6029 \mathrm{p}$ \\
Kotoran Sapi & 1.4921 & 1.4812 & 1.8022 & $1.5926 \mathrm{p}$ \\
\hline Rerata & $1.4829 \mathrm{a}$ & $1.5612 \mathrm{a}$ & $1.6524 \mathrm{a}$ & $(-)$ \\
\hline
\end{tabular}

Keterangan: Rerata yang diikuti huruf yang sama pada baris dan kolom menunjukan tidak ada beda nyata dan tanda (-) menunjukan tidak ada interaksi.

Residu ampas tebu lebih rendah dibanding residu biochar tetapi lebih tinggi dibanding residu kotoran sapi, karena ampas tebu mempunyai kandungan lignin yang tinggi sehingga proses dekomposisi bahan organik lebih lama. Residu kotoran sapi tidak menunjukan kenaikan karena telah mengalami proses pelindian (leaching) dan proses dekomposisi pada kotoran sapi terjadi lebih cepat dan lebih rentan sehingga 
melepaskan $\mathrm{CO}_{2}$ di udara dan kandungan $\mathrm{C}$ organik dalam tanah rendah. Tanah residu biochar tempurung kelapa dengan dosis 15 ton/ha mengalami peningkatan dari 1,29 \% pada penelitian sebelumnya (Herlambang, 2018) menjadi 1,76\%. Hal ini disebabkan karena biochar berkontribusi terhadap cadangan karbon.

Karbon organik tanah setelah tanam kedua tanaman padi menunjukan bahwa rerata perlakuan residu biochar beda nyata dengan kontrol tetapi tidak beda nyata dengan residu perlakuan ampas tebu dan residu perlakuan kotoran sapi. Hasil pengujian menunjukan tidak ada beda nyata pada rerata inkubasi. Hal ini disebabkan karena proses dekomposisi pada tanah sawah berjalan lambat.

\section{C organik Tanah Setelah Tanam Kedua Tanaman Padi}

Setelah tanam kedua diperoleh rerata $\mathrm{C}$ organik sebesar $1.73 \%$, sedangkan pada tanam pertama diperoleh hasil $\mathrm{C}$ organik sebesar $1.76 \%$. Hal ini menunjukan bahwa residu biochar masih dapat mempertahankan nilai $\mathrm{C}$ organik setelah tanam pertama sampai setelah tanam kedua. $\mathrm{C}$ organik dalam biochar dapat bertahan lama dan ditambah bahan organik dari sisa akar pada saat panen. Waktu inkubasi 2 bulan residu perlakuan biochar tempurung kelapa mengalami penurunan, hal itu disebabkan karena karbon mengalami pelindian dan menjadi $\mathrm{CO}_{2}$ diudara. $\mathrm{C}$ organik ini termasuk dalam harkat rendah, hal itu menunjukan bahwa top soil tanah Anthraquic Typic Epiaquepts Potorono sudah hilang yang disebabkan karena tanah sebelumnya yang digunakan untuk tambang batu bata.

Tabel 3. C organik (\%) tanah setelah tanam kedua tanaman padi pada Anthraquic Typic Epiaquepts Potorono, Yogyakarta

\begin{tabular}{lcccc}
\hline \multirow{2}{*}{\multicolumn{1}{c}{ Perlakuan }} & \multicolumn{2}{c}{ Inkubasi sebelum tanam pertama } & \multirow{2}{*}{ Rerata } \\
\cline { 2 - 4 } & 1 bulan & 2 bulan & 3 bulan & \\
\hline Kontrol & 1.2458 & 1.3650 & 1.3747 & $1.3285 \mathrm{q}$ \\
Biochar Tempurung kelapa & .9328 & 1.6053 & 1.6418 & $1.7267 \mathrm{p}$ \\
Ampas Tebu & 1.5097 & 1.4407 & 1.5078 & $1.4861 \mathrm{pq}$ \\
Kotoran Sapi & 1.2987 & 1.5066 & 1.6014 & $1.4689 \mathrm{pq}$ \\
\hline Rerata & $1.4968 \mathrm{a}$ & $1.4794 \mathrm{a}$ & $1.5314 \mathrm{a}$ & $(-)$ \\
\hline
\end{tabular}

Keterangan: Rerata yang diikuti huruf yang sama pada baris dan kolom menunjukan tidak ada beda nyata dan tanda (-) menunjukan tidak ada interaksi.

\section{N-Total Tanah Setelah Tanam Pertama Tanaman Padi}

Residu perlakuan kontrol menunjukan bahwa ada beda nyata dengan residu perlakuan biochar dan residu perlakuan ampas tebu. Hal tersebut disebabkan karena nitrogen dalam perlakuan kontrol tanam pertama semakin berkurang karena sifat nitrogen yang mobile. Akan tetapi pada tanah residu kotoran sapi dengan tanah residu biochar tidak beda nyata karena biochar mampu menyimpan unsur hara Nitrogen lebih lama dalam tanah. Residu perlakuan kotoran sapi memiliki nilai tertinggi pada residu perlakuan kotoran sapi. Peningkatan $\mathrm{N}$-total tanah ini berasal dari mineralisasi bahan organik yang diberikan. Hardjowigeno (2002) menjelaskan bahwa proses hilangnya $\mathrm{N}$ yang ada di dalam tanah dapat disebabkan karena $\mathrm{N}$ diserap oleh tanaman, kemudian $\mathrm{N}$ juga masih dalam bentuk NO yang mudah tercuci oleh adanya air hujan. 
Tabel 4. N-total (\%) tanah setelah tanam pertama tanaman padi pada Anthraquic Typic Epiaquepts Potorono, Yogyakarta

\begin{tabular}{lcccc}
\hline \multirow{2}{*}{ Perlakuan } & \multicolumn{2}{c}{ Inkubasi sebelum tanam pertama } & \multirow{2}{*}{ Rerata } \\
\cline { 2 - 4 } & 1 bulan & 2 bulan & 3 bulan & \\
\hline Kontrol & 0.08 & 0.08 & 0.08 & $0.08 \mathrm{q}$ \\
Biochar Tempurung Kelapa & 0.08 & 0.09 & 0.10 & $0.09 \mathrm{p}$ \\
Ampas tebu & 0.09 & 0.09 & 0.09 & $0.09 \mathrm{p}$ \\
Kotoran sapi & 0.10 & 0.10 & 0.09 & $0.09 \mathrm{p}$ \\
\hline Rerata & $0.08 \mathrm{a}$ & $0.08 \mathrm{a}$ & $0.08 \mathrm{a}$ & $(-)$ \\
\hline
\end{tabular}

Keterangan: Rerata yang diikuti huruf yang sama pada baris dan kolom menunjukan tidak ada beda nyata dan tanda (-) menunjukan tidak ada interaksi.

\section{N-total Tanah Setelah Tanam Kedua Tanaman Padi}

$\mathrm{N}$-total tanah setelah tanam kedua tanaman padi dengan sidik ragam menunjukan bahwa residu perlakuan biochar dan residu perlakuan kotoran sapi dan residu perlakuan ampas tebu mendapatkan hasil yang tidak beda nyata. Hasil N-total ini termasuk dalam harkat yang rendah hal ini disebabkan karena $\mathrm{N}$ bersifat mobile karena mengalami proses denitrifikasi yang berubah menjadi $\mathrm{NO}_{2}$ di udara sehingga menjadi tidak tersedia.Nilai $\mathrm{N}$ - total tertinggi diperoleh pada residu perlakuan biochar. Biochar memiliki kapasitas menahan air yang tinggi, sehingga dapat menjaga unsur hara $\mathrm{N}$ agar tidak mudah tercuci dan menjadikannya lebih tersedia (Herlambang et al., 2019). Residu ampas tebu mengalami penurunan karena telah menguap di udara dan mengalami dekomposisi sehingga kandungan nitrogen dalam tanah menurun.

Tabel 5. N-total (\%) tanah setelah tanam kedua tanaman padi pada Anthraquic Typic Epiaquepts Potorono, Yogyakarta

\begin{tabular}{lcccc}
\hline \multirow{2}{*}{ Perlakuan } & \multicolumn{2}{c}{ Inkubasi sebelum tanam pertama } & \multirow{2}{*}{ Rerata } \\
\cline { 2 - 4 } & 1 bulan & 2 bulan & 3 bulan & \\
\hline Kontrol & 0.09 & 0.09 & 0.10 & $0.09 \mathrm{p}$ \\
Biochar Tempurung kelapa & 0.11 & 0.11 & 0.09 & $0.10 \mathrm{p}$ \\
Ampas Tebu & 0.10 & 0.09 & 0.08 & $0.09 \mathrm{p}$ \\
Kotoran Sapi & 0.09 & 0.11 & 0.10 & $0.010 \mathrm{p}$ \\
\hline Rerata & $0.10 \mathrm{a}$ & $0.10 \mathrm{a}$ & $0.09 \mathrm{a}$ & $(-)$ \\
\hline
\end{tabular}

Keterangan: Rerata yang diikuti huruf yang sama pada baris dan kolom menunjukan tidak ada beda nyata dan tanda (-) menunjukan tidak ada interaksi.

\section{P-tersedia Tanah Setelah Tanam Pertama Tanaman Padi}

Tanah dengan residu perlakuan biochar tempurung kelapa ada beda nyata dengan kontrol tetapi tidak beda nyata dengan residu perlakuan ampas tebu dan residu perlakuan kotoran sapi. Faktor perlakuan kedua yaitu inkubasi menunjukkan inkubasi 3 bulan berbeda nyata dengan inkubasi 1 bulan dan 2 bulan. P-tersedia menurun dengan bertambahnya masa inkubasi disebabkan karena $\mathrm{P}$ dijerap oleh $\mathrm{Al}$ dan Fe maupun dijerap oleh koloid anorganik tanah. Tanah dengan residu kotoran 
sapi mempunyai $\mathrm{P}$ paling tinggi. Hal tersebut sesuai dengan Soepardi (1983) menyatakan bahwa sumber utama P-tersedia tanah, disamping dari pelapukan yang berasal dari bebatuan atau bahan induk juga berasal dari proses mineralisasi Porganik hasil dari dekomposisi sisa tanaman dan hewan. Terdapat asam-asam amino yang terdapat di kotoran sapi mengandung anion-anion organik dari asam-asam organik yang larut dalam kotoran sapi akan mengkhelat Al dan Fe sehingga unsur hara $\mathrm{P}$ dapat tersedia. Tanah residu biochar berbeda nyata dengan ampas tebu dan kotoran sapi tetapi pada residu perlakuan ampas tebu tidak beda nyata dengan kontrol. Hasil pengujian menunjukan tidak ada beda nyata pada rerata inkubasi, baik rerata inkubasi 1 bulan, rerata inkubasi 2 bulan dan rerata inkubasi 3 bulan.

Tabel 6. P-tersedia (ppm) tanah setelah tanam pertama tanaman padi pada Anthraquic Typic Epiaquepts Potorono, Yogyakarta

\begin{tabular}{lcccc}
\hline \multirow{2}{*}{ Perlakuan } & \multicolumn{2}{c}{ Inkubasi sebelum tanam pertama } & \multirow{2}{*}{ Rerata } \\
\cline { 2 - 4 } & 1 bulan & 2 bulan & 3 bulan & \\
\hline Kontrol & 14.00 & 15.00 & 11.50 & $13.50 \mathrm{q}$ \\
Biochar Tempurung Kelapa & 19.17 & 20.50 & 14.83 & $18.17 \mathrm{p}$ \\
Ampas Tebu & 18.50 & 18.52 & 12.50 & $16.51 \mathrm{pq}$ \\
Kotoran Sapi & 20.17 & 17.00 & 18.00 & $18.39 \mathrm{p}$ \\
\hline Rerata & $17.96 \mathrm{a}$ & $17.75 \mathrm{a}$ & $14.21 \mathrm{~b}$ & $(-)$ \\
\hline
\end{tabular}

Keterangan: Rerata yang diikuti huruf (a dan b) pada baris menunjukan adanya beda nyata dan rerata yang menunjukan huruf ( $p$ dan $q$ ) menunjukan adanya beda nyata dan tanda (-) menunjukan tidak ada interaksi.

\section{P-tersedia Tanah Setelah Tanam Kedua Tanaman Padi}

Tanah residu biochar setelah tanam kedua memiliki kandungan P-tersedia paling tinggi. Kandungan P-tersedia pada residu biochar juga meningkat pada tanam kedua. Adanya residu biochar dalam tanah dapat mempertahankan rata-rata nilai P-tersedia di bandingkan yang tanpa residu biochar, hal ini sesuai menurut Samira (2012) yaitu biochar dapat meningkatkan P-tersedia pada tanah alkalin karena reaktivitas $\mathrm{P}$ dengan tanah meningkat serta membentuk senyawa tidak terlarut dengan Ca (De Luca et al., 2009). Berbeda dengan bahan organik lainnya di dalam tanah biochar menjerap unsur hara P lebih kuat (Cheng et al., 2006).

Tabel 7. P-tersedia (ppm) tanah setelah tanam kedua tanaman padi pada Anthraquic Typic Epiaquepts Potorono, Yogyakarta

\begin{tabular}{lcccc}
\hline \multirow{2}{*}{ Perlakuan } & \multicolumn{2}{c}{ Inkubasi sebelum tanam pertama } & \multirow{2}{*}{ Rerata } \\
\cline { 2 - 4 } & $\mathbf{1}$ bulan & 2 bulan & $\mathbf{3 ~ b u l a n}$ & \\
\hline Kontrol & 6.66 & 9.32 & 7.77 & $7.91 \mathrm{r}$ \\
Biochar Tempurung Kelapa & 19.76 & 21.30 & 21.71 & $20.32 \mathrm{p}$ \\
Ampas Tebu & 6.35 & 6.89 & 6.39 & $6.54 \mathrm{r}$ \\
Kotoran Sapi & 9.48 & 13.42 & 14.15 & $12.35 \mathrm{q}$ \\
\hline Rerata & $10.95 \mathrm{a}$ & $11.90 \mathrm{a}$ & $12.50 \mathrm{a}$ & $(-)$ \\
\hline
\end{tabular}

Keterangan: Rerata yang diikuti huruf yang sama pada baris dan kolom menunjukan tidak ada beda nyata dan tanda (-) menunjukan tidak ada interaksi. 


\section{Kapasitas Pertukaran Kation Tanah Setelah Tanam Pertama Tanaman Padi}

Kapasitas Pertukaran kation tanah setelah tanam pertama dengan sidik ragam menunjukan bahwa residu perlakuan biochar tempurung kelapa, residu perlakuan kotoran sapi dan residu kotoran ampas tebu mendapatkan hasil yang tidak beda nyata. Kapasitas Pertukaran Kation tidak beda nyata terlihat dari parameter $\mathrm{C}$ organik yang masih rendah, karena $\mathrm{C}$ organik menghasilkan bahan organik yang memiliki muatan negatif yang sangattinggi dan belum tersedia dikarenakan proses dekomposisi tanah sawah terjadi lambat. Residu pemberian perlakuan biochar tempurung kelapa, kotoran sapi dan ampas tebu terhadap tanah Anthraquic Typic Epiaquepts setelah tanam pertama juga menunjukan tidak ada interaksi semua perlakuannya.

Tabel 8. Kapasitas Pertukaran Kation ( $\mathrm{cmol}(+) \mathrm{kg}-1)$ tanah setelah tanam tanaman padi pada Anthraquic Typic Epiaquepts di Potorono, Yogyakarta

\begin{tabular}{lcccc}
\hline \multirow{2}{*}{ Perlakuan } & \multicolumn{2}{c}{ Inkubasi Sebelum Tanam Pertama } & \multirow{2}{*}{ Rerata } \\
\cline { 2 - 4 } & 1 bulan & 2 bulan & 3 bulan & \\
\hline Kontrol & 3.83 & 4.91 & 5.16 & $4.63 \mathrm{p}$ \\
Biochar Tempurung Kelapa & 4.22 & 5.78 & 7.50 & $5.83 \mathrm{p}$ \\
Ampas tebu & 2.90 & 3.94 & 7.99 & $4.94 \mathrm{p}$ \\
Kotoran sapi & 3.37 & 5.50 & 6.95 & $5.27 \mathrm{p}$ \\
\hline Rerata & $3.58 \mathrm{c}$ & $5.03 \mathrm{~b}$ & $6.90 \mathrm{a}$ & $(-)$ \\
\hline
\end{tabular}

Keterangan: Rerata yang diikuti huruf yang sama pada baris dan kolom menunjukan tidak ada beda nyata dan tanda (-) menunjukan tidak ada interaksi

\section{Kapasitas Pertukaran Kation Tanah Setelah Tanam Kedua Tanaman Padi}

KPK tanah Anthraquic Typic Epiaquepts di Potorono setelah tanam kedua menunjukan bahwa residu perlakuan biochar tempurung kelapa, residu kotoran sapi dan residu ampas tebui mendapatkan hasil yang tidak beda nyata. Kapasitas Pertukaran Kation tidak beda nyata terlihat dari parameter $\mathrm{C}$ organik pada musim tanam kedua yang masih rendah, kadar $\mathrm{C}$ organik pada musim tanam kedua juga berkurang dari musim tanam pertama karena dekomposisi sehingga karbon hilang dalam bentuk $\mathrm{CO}_{2}$. Residu pemberian perlakuan biochar tempurung kelapa, ampas tebu dan kotoran sapi terhadap tanah Anthraquic Typic Epiaquepts setelah tanam kedua juga menunjukan tidak ada interaksi semua perlakuannya pada parameter Kapasitas Pertukaran Kation. Peningkatan persentase bahan organik dan KPK tersebut menunjukkan bahwa biochar memberikan kontribusi bahan organik dan Kapasitas Pertukaran Kation terhadap tanah residu. Laird et al., (2010), menunjukan bahwa perlakuan biochar berkontribusi terhadap penurunan pencucian bahan organik tanah dan proses pembuatan biochar, oksidasi biologis yang lambat menghasilkan unit karboksilat pada bagian tepi dari kondensasi aromatik yang memiliki intensitas yang kuat pada bagian dari arang yang meningkatkan Kapasitas Pertukaran Kation. Kapasitas Pertukaran Kation pada waktu 3 bulan menunjukan penurunan hal ini disebabkan karena bahan organik sudah terlindi dan terangkut panen. Residu ampas tebu juga menunjukan hasil yang paling rendah dibanding residu yang lainnya karena ampas tebu lebih sulit terdekomposisi. 
Tabel 9. Kapasitas Pertukaran Kation $\left(\mathrm{cmol}(+) \mathrm{kg}^{-1}\right)$ tanah setelah tanam kedua tanaman padi Anthraquic Typic Epiaquepts di Potorono

\begin{tabular}{lcccc}
\hline \multirow{2}{*}{ Perlakuan } & \multicolumn{4}{c}{ Inkubasi sebelum tanam pertama } \\
\cline { 2 - 4 } & 1 bulan & 2 bulan & 3 bulan & \\
\hline Kontrol & 7.16 & 6.65 & 6.64 & $6.83 \mathrm{p}$ \\
Biochar Tempurung Kelapa & 8.45 & 7.78 & 7.31 & $7.85 \mathrm{p}$ \\
Ampas Tebu & 6.91 & 5.94 & 5.74 & $6.19 \mathrm{p}$ \\
Kotoran Sapi & 7.80 & 7.16 & 8.57 & $7.84 \mathrm{p}$ \\
\hline Rerata & $7.58 \mathrm{a}$ & $6.88 \mathrm{a}$ & $7.06 \mathrm{a}$ & $(-)$ \\
\hline
\end{tabular}

Keterangan: Rerata yang diikuti huruf yang sama pada baris dan kolom menunjukan tidak ada beda nyata dan tanda (-) menunjukan tidak ada interaksi.

\section{9. $\mathrm{pH}\left(\mathrm{H}_{2} \mathrm{O}\right)$ Tanah}

Nilai $\mathrm{pH}\left(\mathrm{H}_{2} \mathrm{O}\right)$ tanah setelah tanam pertama dan kedua (Tabel 10 dan Tabel 11) menunjukkan bahwa residu perlakuan biochar tempurung kelapa, residu perlakuan kotoran sapi, residu perlakuan ampas tebu dan residu perlakuan kontrol mendapatkan hasil yang tidak beda nyata.

Tabel 10. $\mathrm{pH}\left(\mathrm{H}_{2} \mathrm{O}\right)$ tanah setelah tanam pertama tanaman padi di Potorono, Yogyakarta

\begin{tabular}{lcccc}
\hline \multirow{2}{*}{ Perlakuan } & \multicolumn{3}{c}{ Inkubasi sebelum tanam pertama } & \multirow{2}{*}{ Rerata } \\
\cline { 2 - 5 } & 1 bulan & 2 bulan & 3 bulan & \\
\hline Kontrol & 6.61 & 6.66 & 6.77 & $6.68 \mathrm{q}$ \\
Biochar tempurung kelapa & 6.93 & 7.00 & 7.05 & $6.99 \mathrm{p}$ \\
Ampas tebu & 6.91 & 6.87 & 6.92 & $6.90 \mathrm{p}$ \\
Kotoran sapi & 6.85 & 7.03 & 7.05 & $6.97 \mathrm{p}$ \\
\hline Rerata & $6.82 \mathrm{a}$ & $6.89 \mathrm{a}$ & $6.95 \mathrm{a}$ & $(-)$ \\
\hline
\end{tabular}

Keterangan: Rerata yang diikuti huruf yang sama pada baris dan kolom menunjukan tidak ada beda nyata dan tanda (-) menunjukan tidak ada interaksi.

Tabel 11. $\mathrm{pH}\left(\mathrm{H}_{2} \mathrm{O}\right)$ tanah setelah tanam kedua tanaman padi pada Anthraquic Typic Epiaquepts Potorono, Yogyakarta

\begin{tabular}{lcccc}
\hline \multirow{2}{*}{ Perlakuan } & \multicolumn{2}{c}{ Inkubasi sebelum tanam pertama } & \multirow{2}{*}{ Rerata } \\
\cline { 2 - 4 } & 1 bulan & 2 bulan & 3 bulan & \\
\hline Kontrol & 5.94 & 6.08 & 6.18 & $6.07 \mathrm{p}$ \\
Biochar tempurung kelapa & 6.27 & 6.34 & 6.50 & $6.37 \mathrm{p}$ \\
Ampas tebu & 6.24 & 6.28 & 6.31 & $6.27 \mathrm{p}$ \\
Kotoran sapi & 6.08 & 6.13 & 6.28 & $6.15 \mathrm{p}$ \\
\hline Rerata & $6.13 \mathrm{a}$ & $6.21 \mathrm{a}$ & $6.32 \mathrm{a}$ & $(-)$
\end{tabular}

Keterangan: Rerata yang diikuti huruf yang sama pada baris dan kolom menunjukan tidak ada beda nyata dan tanda (-) menunjukan tidak ada interaksi. 
Residu pemberian perlakuan biochar tempurung kelapa residu perlakuan kotoran sapi, residu perlakuan ampas tebu dan residu perlakuan kontrol terhadap tanah Anthraquic Typic Epiaquepts juga menunjukan tidak ada interaksi semua perlakuannya pada parameter $\mathrm{pH}\left(\mathrm{H}_{2} \mathrm{O}\right) \cdot \mathrm{pH}\left(\mathrm{H}_{2} \mathrm{O}\right)$ tanah termasuk dalam harkat netral, hal ini karena fenomena dalam penggenangan tanah sawah. Penggenangan dengan air irigasi mengakibatkan ion $\mathrm{H}^{+}$pada kompleks jerapan tanah menjadi rendah.

Tabel 11. pH (H2O) tanah setelah tanam kedua tanaman padi pada Anthraquic Typic Epiaquepts Potorono, Yogyakarta

\begin{tabular}{lcccc}
\hline \multirow{2}{*}{ Perlakuan } & \multicolumn{3}{c}{ Inkubasi sebelum tanam pertama } & \multirow{2}{*}{ Rerata } \\
\cline { 2 - 4 } & 1 bulan & 2 bulan & 3 bulan & \\
\hline Kontrol & 5.94 & 6.08 & 6.18 & $6.07 \mathrm{p}$ \\
Biochar tempurung kelapa & 6.27 & 6.34 & 6.50 & $6.37 \mathrm{p}$ \\
Ampas tebu & 6.24 & 6.28 & 6.31 & $6.27 \mathrm{p}$ \\
Kotoran sapi & 6.08 & 6.13 & 6.28 & $6.15 \mathrm{p}$ \\
\hline Rerata & $6.13 \mathrm{a}$ & $6.21 \mathrm{a}$ & $6.32 \mathrm{a}$ & $(-)$ \\
\hline
\end{tabular}

Keterangan: Rerata yang diikuti huruf yang sama pada baris dan kolom menunjukan tidak ada beda nyata dan tanda (-) menunjukan tidak ada interaksi.

\section{KESIMPULAN}

Tanah dengan residu Biochar tempurung kelapa lebih baik daripada tanah dengan residu kotoran sapi dan tanah dengan residu ampas tebu pada setelah tanam pertama dan kedua tanaman padi. Tanah dengan residu Biochar tempurung kelapa menunjukkan tidak beda nyata pada $\mathrm{C}$ organik, $\mathrm{N}$-total, Kapasitas Pertukaran Kation dan $\mathrm{pH}\left(\mathrm{H}_{2} \mathrm{O}\right)$ tanah. Namun berbeda nyata pada P-tersedia tanah. Tanah dengan residu Biochar tempurung kelapa menunjukkan hasil terbaik pada $\mathrm{C}$ organik yaitu $1,76 \%$, Kapasitas Pertukaran Kation yaitu 7,85 $\mathrm{Cmol}(+) \mathrm{kg}^{-1}$ dan $\mathrm{pH}\left(\mathrm{H}_{2} \mathrm{O}\right)$ tanah yaitu 6,99. Inkubasi 3 bulan menunjukkan beda nyata pada Kapasitas Pertukaran Kation dan P-tersedia tanah.

\section{DAFTAR PUSTAKA}

Afifi, R. 2019. Potensial Redoks Anthraquic Typic Epiaquepts pada Aplikasi Biochar dan Bahan Organik. [Skripsi] Fakultas Pertanian: Universitas Pembangunan Nasional Veteran Yogyakarta.

Chen, Y.P., P.D. Rekha, A.B. Arunshen, W.A. Lai and C.C. Young. 2006. Phosphate Solubilizing Bacteria From Subtropical Soil And Their Tricalcium Phosphate Solubilizing Abilities. Appl. Soil Ecol, 34:33-41.

De Lucca, T.H., MacKenzie, M.D., dan Gundale, M.J. 2006. Biochar Effects On Soil Nutrient Transformation. Earthscan. London :251-255.

Glaser, B., L. Haumaier, G. Guggenberger and W. Zech. 2001. The 'Terra Preta' Phenomenon: A Model For Sustainable Agriculture In The Humid Tropics. Naturwissenschaften 88(1): 37-41. 
Guntoro. 2003. The Effect of Bagasse Compost Application on Nutrient Uptake and Growth of Sugarcane (Saccharum officinarum). Buletin Agronomi 31(3): 114119.

Hardjowigeno. 2002. Ilmu Tanah. Jakarta: Akademika Pressindo.

Herlambang, S., Santosa, AZ. P. B., Sutiono, H. T., \& Rina N, S. (2018). Pemanfaatan biochar dan limbah organik untuk meningkatkan kadar C-organik tanah pada padi sawah. Laporan akhir ke 2 Penelitian terapan unggulan perguruan tinggi Kemenristek Dikti. UPN "Veteran" Yogyakarta

Herlambang, S., Santosa, AZ. P. B., Sutiono, H. T., \& Rina N, S. (2019). Application of coconut biochar and organic materials to improve soil environmental. IOP Conference Series: Earth and Environmental Science, 347, 012055. https://doi.org/10.1088/1755-1315/347/1/012055.

Laird, D.A. 2008. The Charcoal Vision: A Win-Win-Win Scenario For Simultaneously Producing Bioenergy, Permanently Sequestering Carbon, While Improving Soil And Water Quality. Agronomis J. 100: 178-181.

Samira, D. 2012. Pengaruh Pemupukan NPK dan Residu Biochar Terhadap Sifat Kimia Tanah, Kandungan Hara, dan Hasil Tanaman Padi Sawah (oryza sativa L.) Musim Tanam II. [Thesis]. Universitas Syiah kuala, Banda Aceh.

Setiaji, N. 2018. Pengaruh Pemberian Biochar dan Limbah Organik Terhadap Ketersediaan N dan K Pada Demplot Farming Inceptisols Potorono [Skripsi]. Fakultas Pertanian: Universitas Pembangunan Nasional Veteran Yogyakarta.

Soepardi, G. 1983. Sifat dan Ciri Tanah. Bogor: Fakultas Pertanian Institut Pertanian Bogor.

Sudarsono. 2017. Pengaruh Bahan Organik Terhadap Ketersediaan Fosfor. Buletin Tanah dan Lahan, 1:65-71. 